\title{
Revisiting Implementation of Treaties on Human Rights in The Islamic Court of Aceh, Indonesia: Compliance or Violation?
}

\author{
By Rina Shahriyani Shahrullah*
}

\begin{abstract}
Indonesia has ratified six international treaties in the field of human rights, namely CEDAW, CAT, CERD, CRC, ICESCR, and ICCPR. These international human rights treaties oblige a ratifying state to transform them into their national law; consequently Indonesia as a ratifying state must transform them to its applicable legislation, so that courts in Indonesia can apply them when making decisions. Different from the Religious Courts which are established in other provinces in Indonesia, the Aceh Islamic Court has jurisdiction to decide both private matters and criminal offenses. Since the competencies of this court cover the area of public law, this study aims to examine whether it has implemented the principles or norms of international treaties which have been ratified by Indonesia. To achieve this particular objective, the study adopts normative legal research by focusing on the examination of the Aceh Jinayat Qānūn and Islamic Court decisions. Data used in this study was based on secondary data obtained from official legal documents, books, research reports and journal articles and it was analysed by using the qualitative approach. It was found that the international treaties has never been implemented by the Islamic Court of Aceh because the Court adopts the caning punishments which are considered inhuman and cruel; consequently they violate human rights and the ratified international treaties. It was also found that the Central Indonesian government is silent regarding this matter even though international community and the UN Human Rights Committee called on Indonesia to evaluate the Aceh Jinayat Qānün to comply with the ratified international treaties. It was further found that although the Aceh Jinayat Qānün which imposes the caning execution and considers being cruel and inhuman, people of Aceh remains to support the implementation of the Qānün and have no objections to the Islamic Court decisions.
\end{abstract}

Keywords: International Treaties; Human Rights; Islamic Court; Aceh; Indonesia

\section{Introduction}

Majority of population in Indonesia embrace Islam as their religion. Yet, it does not mean that Islamic Law is implemented in its entirety by all courts in 34 provinces in Indonesia. Aside from Aceh Province, courts in other provinces only implement Islamic Law which is relevant to the matters relating to marriage, inheritance, succession, gifts, and the endowment of money for religious purposes (wakaf), the giving of alms (shadaqah) and Islamic economic matters such as Islamic finance and banking. ${ }^{1}$ Islamic law is integrated into the Indonesian legal

\footnotetext{
*PhD, Head of Postgraduate Study of Law, School of Law, Universitas Internasional Batam, Jalan Gajah Mada, Baloi Sei Ladi, Batam, Indonesia. Email: rina@uib.ac.id.

${ }^{1}$ Presidential Instruction No. 1 of 1991 concerning the Compilation of Islamic Law covers marriage, inheritance and endowment (Wakaf). Religious Court settles all financial, banking and economic
} 
system together with Customary Law (Adat Law), ${ }^{2}$ the Civil Law System with a Dutch Colonial Law model ${ }^{3}$ and to some extent the Common Law System due to a new development of law in Indonesia. ${ }^{4}$ Hence, the Indonesia legal system in principle constitutes a pluralistic legal system.

As a result of pluralistic legal system, the judiciary system in Indonesia consists of state courts (Peradilan Negeri), military courts,, administrative courts and religious courts as it is stated under Article 24 of the 1945 Constitution. Each of the courts has its own appeal court (Pengadilan Tinggi), and the Supreme Court (Mahkamah Agung) is the highest in the hierarchy. The organizations and competencies of Islamic Court are established under the 1989 Religious Judicature Law. ${ }^{5}$ Article 4(1) of the Law stipulates that the first instance courts (Peradilan Agama) should exist in each regency (kabupaten) and municipality (kotamadya), while the Islamic appeal courts (Peradilan Tinggi Agama) are located in every capital of province. ${ }^{6}$

In 2006, the 1989 Religious Judicature Law was amended by the 2006 Religious Judicature Law. The later Law sets up a number of changes relating to the courts' powers, in particular the abolition of the "choice of law" rule relating to inheritance. Based on this Law, Indonesian Muslims are no longer permitted to submit their inheritance cases decided according to the customary law (Adat) in the civil courts. The 2006 Religious Judicature Law also added new competencies to the Islamic courts to include disputes relating to "Shariah Economics" (Ekonomi Syariah). ${ }^{7}$ In 2009, the second amendment was made to the 1989 Religious Judicature Law. In order to improve the uniformity in the implementation of Islamic law within the jurisdiction of Islamic courts, ${ }^{8}$ in 1991 the Indonesian President issued a Presidential Instruction No. 1 of 1991 concerning the Compilation of Islamic Law (Kompilasi Hukum Islam). The Compilation of Islamic Law consists of Three Books, namely Book One on Marriage, Book Two on Inheritance, and Book Three on Charity. The Compilation is implemented by the Religious Courts in Indonesia except Aceh Province. Based on the contents of the Compilation and the 2006 Religious Judicature Law, it is obvious that the

matters based on the Islamic Law (Syariah) based on Law No.3 of 2006 as amended by Law No.3 of 2009 concerning the Second Amendment to Law No.7 of 1989 concerning Religious Court Judicature.

${ }^{2}$ Law No. 5 of 1960 concerning Agrarian Law (Land Law) is based on Adat Law.

${ }^{3}$ The Civil Law System is inherited by the Dutch Colonial Law and it strongly influences the Indonesian style of legal thoughts, structure of legal institutions, legal classification and procedures. See Marzuki (2012) at 26.

${ }^{4}$ Law No. 20 of 2001 concerning the Amendment to Law No. 31/1999 on the Eradication of the Criminal Act of Corruption adopts the approaches of the Common Law.

${ }^{5}$ Law No.7 of 1989 concerning Religious Judicature.

${ }^{6}$ Article 4(2) of Law No.7 of 1989 concerning Religious Judicature.

${ }^{7}$ Elucidation of the 2006 Religious Judicature Law states that Syariah Economics are commercial activities carried out according to the principles of the Shari a."The elucidation also includes a nonexhaustive list of subjects encompassed by 'ekonomi Syariah', including Shari'a-compliant banking, finance, microfinance institutions, insurance, fund management, time deposits, securities, pawn brokerage, pension funds, and other business transactions.

${ }^{8}$ Mawardi (2003) at 125,127. 
jurisdiction of the Religious Courts in other provinces are limited to private and Islamic economics matters only.

Different from other provinces in Indonesia, since 1999 Aceh Province has formally implemented Islamic Law through Law No.44 of 1999 which recognized the "Special Status of the Province of Aceh Special Region in the fields of religion, education, and customary law (Adat)". ${ }^{9}$ Other legal sources which render full authority to Aceh Province to implement Islamic Law are Law No. 18 of 2001 on Special Autonomy for the Province of Aceh, and Law No. 11 of 2006 concerning the Government of Aceh. The Laws provides the authority to Aceh Province to formulate its regulations (Qānūn) at provincial level based on Islamic Law. Table 1 shows the Hierarchy of Rules in Aceh Province.

Table 1. Legal Hierarchy in Aceh Province

\begin{tabular}{|c|c|c|}
\hline $\begin{array}{l}\text { Types and National } \\
\text { Hierarchy of Rules }\end{array}$ & $\begin{array}{c}\text { Types and Hierarchy of } \\
\text { Rules for Special } \\
\text { Autonomy }\end{array}$ & $\begin{array}{c}\text { Types and Hierarchy of } \\
\text { Rules based on Islamic } \\
\text { Law }\end{array}$ \\
\hline $\begin{array}{l}\text { The Constitution of the } \\
\text { Republic of Indonesia of } \\
1945\end{array}$ & $\begin{array}{l}\text { The Constitution of the } \\
\text { Republic of Indonesia of } \\
1945\end{array}$ & $\begin{array}{l}\text { The Constitution of the } \\
\text { Republic of Indonesia of } \\
1945\end{array}$ \\
\hline $\begin{array}{l}\text { People's Consultative } \\
\text { Council Decree }\end{array}$ & $\begin{array}{c}\text { People's Consultative } \\
\text { Council Decree }\end{array}$ & \\
\hline $\begin{array}{l}\text { Law/Government } \\
\text { Regulation In Lieu of Law }\end{array}$ & $\begin{array}{l}\text { Law/Government } \\
\text { Regulation In Lieu of Law }\end{array}$ & $\begin{array}{c}\text { Law/Government } \\
\text { Regulation In Lieu of Law/ } \\
\text { Islamic Law } \\
\text { (al-Qur'an/Sunnah/ Ijtihad/ } \\
\text { Mazhab) }\end{array}$ \\
\hline \multicolumn{3}{|l|}{ Government Regulation } \\
\hline Presidential Regulation & Presidential Regulation & \\
\hline $\begin{array}{l}\text { Province Regulation/ } \\
\text { Regency/Municipality } \\
\text { Regulation }\end{array}$ & $\begin{array}{l}\text { Qānūn of Aceh/ Qānūn of } \\
\text { Regency/Municipality/ } \\
\text { Reusam Gampong }\end{array}$ & Qānūn of Aceh \\
\hline & & $\begin{array}{c}\text { Qānūn of } \\
\text { Regency/Municipality/ } \\
\text { Reusam Gampong }\end{array}$ \\
\hline
\end{tabular}

Law No.11 of 2006 also gives a special authority to Aceh Province to issue Qānūn which covers the field of family matters (ahwal al-syakh siyah), civil matters (muamalah) and criminal matters (jinayat). Consequently if a Qānūn is contrary to the Government Regulation, Presidential Regulation, and Province Regulation/Regency/Municipality Regulation, it is not automatically cancelled. This is because such regulations must be adjusted to Law No.11 of 2006 as an umbrella legislation for Qānūn. ${ }^{11}$ Aceh Province has Qānūn No.11 of 2002 on the Implementation of Islamic Law on the Fields of Doctrine (Akidah), Ritual

\footnotetext{
${ }^{9}$ Cammack \& Feener (2012) at 38.

${ }^{10}$ Abubakar (2007) at 18.

${ }^{11}$ Kasim (2011) at 13.
} 
Practices (Ibadah), Markers of Identity (Syiar Islam), Qānūn No. 7 of 2004 on Obligatory Charitable Giving (zakat), and Qānūn No.10 of 2007 on the Institution of Obligatory Charitable Giving (Baitul Mal). ${ }^{12}$ Previously, it has Qānūn No. 12 of 2003 on the Consumption of Alcohol (Khamr), Qānūn No.13 of 2003 on Gambling (Maysir), and Qānūn No.14 of 2003 on Improper Covert Association (Khalwat). Yet, they were repealed when Qānūn No.6 of 2014 on Jinayat Law (Criminal Law) was issued. To strengthen the implementation of Islamic Law in Aceh Province, the Indonesian President issued a Presidential Decree No.11 of 2003 concerning Islamic Court (Mahkamah Syar'iyah) and it was followed by the Decision of the Chief of Indonesian Supreme Court No.KMA/070/SK/2004 which delegates the authority of general courts to the Islamic Court (Mahkamah Syar'iyah) in Aceh Province. ${ }^{13}$ Different from the Religious Court in other provinces, the Islamic Court of Aceh Province decides both private matters and criminal offenses.

Since the Islamic Court has jurisdiction to decide both criminal and private cases under the Islamic Law, controversies arise regarding the punishments imposed by the Court. This is because the form of whipping for example is not only foreign to the higher level of legislation in Indonesia, but also to the international legal instruments which are ratified by this country. In this regard, it must ensure that its legislative products at the national and regional level, both the existing ones or and those that will be formulated later, must comply with the provisions of the ratified international treaties. Accordingly, Qānūn as 'a statutory regulation similar to provincial regional regulation which governs the administering of government and life of Aceh community ${ }^{14}$ must also be in accordance with the treaties ratified by Indonesia. Up to the present, Indonesia has ratified six major international human rights treaties, namely:

a. International Convention on the Elimination of All Forms of Discrimination against Women (CEDAW), ratified by Law 7 of 1984;

b. Convention International Against Torture and Treatment or Punishment other Cruel, Inhuman and Degrading Man's Dignity (CAT), ratified by Law 5 of 1998;

c. International Convention on Elimination of All Forms of Racial Discrimination (CERD), ratified with Law 29 of 1999;

d. International Convention on the Rights of the Child (CRC), ratified through Presidential Decree No. 36 of 1990;

e. International Covenant on Economic, Social and Cultural Rights (ICESCR), ratified by Law 11 of 2005 ;

f. The International Covenant on Civil and Political Rights (ICCPR), ratified by law 12 of $2005 .{ }^{15}$

\footnotetext{
${ }^{12}$ Cammack \& Feener (2012) at 39.

${ }^{13}$ Kasim (2011) at 12.

${ }^{14}$ Article 1(21) of Law No.11 of 2006.

${ }^{15} \mathrm{Kasim}$ (2011) at 14.
} 


\section{Literature Review on Punishments in Islamic Law}

Based on Islamic Law, there are six major offenses which are referred to the offenses of hudud or hadd punishment. ${ }^{16}$ They are drinking of alcohol, theft, armed robbery, illicit sexual relations, slanderous accusation of unchasity, and apostasy. ${ }^{17}$ Their penalties are prescribed in the Qur'an ${ }^{18}$ or the Sunnah. ${ }^{19}$ Islamic Law also prescribes punishment for homicide and the infliction of injury which could be either as Qisas (retaliation) or the payment of Diya (blood-money). ${ }^{20}$ Relatives of the deliberate murder may demand diya instead of qisas. ${ }^{21}$ Table 2 shows the category of hudud and qisas offenses and their punishments.

Table 2. Criminal Offenses (Jarimah) and Punishments (Uqubat)

\begin{tabular}{|c|c|c|c|}
\hline $\begin{array}{l}\text { Criminal Offenses } \\
\text { (Jarīmah) }\end{array}$ & $\begin{array}{c}\text { Category of } \\
\text { Offenses }\end{array}$ & $\begin{array}{l}\text { Punishment } \\
\text { ('Uqūbat) }\end{array}$ & Sources \\
\hline Theft (al-Sariqa) & Hudud & Amputation of hand & $\begin{array}{l}\text { Qur'an: al-Ma'idah: } \\
38 .\end{array}$ \\
\hline $\begin{array}{l}\text { Armed Robbery (al- } \\
\text { Hiraba) }\end{array}$ & Hudud & $\begin{array}{c}\text { Death penalty, } \\
\text { crucifixion, cutting off } \\
\text { the hands and feet on } \\
\text { the opposite sites, } \\
\text { banishment }\end{array}$ & $\begin{array}{c}\text { Qur'an: al-Ma'idah: } \\
\quad 33-34 .\end{array}$ \\
\hline $\begin{array}{l}\text { Illicit Sexual } \\
\text { Relations (al-Zina) }\end{array}$ & Hudud & 100 lashes & $\begin{array}{l}\text { Qur'an: al-Nur: } 2 ; \\
\text { Qur'an: al-Anfal:38. }\end{array}$ \\
\hline $\begin{array}{l}\text { False Accusations of } \\
\text { Unchastity (al- } \\
\text { Qadhf) }\end{array}$ & Hudud & 80 lashes & Qur'an: al-Nur: 4. \\
\hline $\begin{array}{l}\text { Consumption of } \\
\text { Alcohol (al-Khamr) }\end{array}$ & Hudud & 40 lashes & $\begin{array}{c}\text { Sunna (practices } \\
\text { established by } \\
\text { Prophet Muhammad } \\
\text { Peace be Upon Him). }\end{array}$ \\
\hline Apostasy (Murtadd) & Hudud & Death penalty & $\begin{array}{c}\text { Sunna (practices } \\
\text { established by } \\
\text { Prophet Muhammad } \\
\text { Peace be Upon Him). }\end{array}$ \\
\hline Homicide & $\begin{array}{c}\text { Qisas or } \\
\text { Diya }\end{array}$ & $\begin{array}{c}\text { Retaliation or blood- } \\
\text { money }\end{array}$ & $\begin{array}{c}\text { Qur'an: al-Baqarah: } \\
178-179 .\end{array}$ \\
\hline
\end{tabular}

Source: Abū Zahrah. ${ }^{22}$

\footnotetext{
${ }^{16}$ El-Awa (1982) at 1.

${ }^{17}$ El-Awa (1982) at 1-2.

${ }^{18}$ The Qur'an is the literal word of God, which He revealed to His Prophet Muhammad peace be upon Him through the Angel Gabriel. See Ibrahim (1997) at 5.

${ }^{19}$ The Sunnah is comprised of hadeeths, which are reliably trasmitted reports by the companions of Prophet Muhammad peace be upon Him of what he said, did, or approved of. See Ibrahim (1997) at 49.

${ }^{20}$ El-Awa (1982) at 71.

${ }^{21}$ El-Awa (1982) at 71.

${ }^{22}$ Zahrah at 76.
} 
Apart from hudud and qisas, other offenses in Islamic Law are categorized as Ta'zir (discretionary punishment). ${ }^{23}$ The ultimate objectives of Ta'zir are to punish wrong deeds which may do harm to the society or to the rights of an individual'. ${ }^{24}$ In this regard, its objectives are to prevent further commission of crimes and to reform punishment the offender'. ${ }^{25}$ Ta'zir constitutes a discretionary power of judges; consequently they are free to determine the types of offenses and their punishments. ${ }^{26}$ The punishments of Ta'zir are admonition (al-Wa'z), reprimand (al-Tawbikh), threat (al-Tahdid), boycott (al-Hajr), public disclosure (al-Tashhir), fines and the seizure of property (al-Gharamah wal-Musadarah), imprisonment (al-Habs), flogging (al-Jald), death penalty (al-Ta zir bil Qatl).

According to Suparyanto, ${ }^{27}$ punishments in Islamic Law contain specific purposes, namely:

a. Punishment is to prevent offenders to repeat the same crimes. In addition, it also prevents others from conducting such crimes since they understand the consequences or punishments that can be imposed on them.

b. Punishment aims to educate offenders. In this regard, they abstain from conducting the crimes not only because of fearing the punishment, but because of their self-consciousness and willingness of obtaining forgiveness from God.

The execution of punishment under Islamic Law requires some conditions to be met in order to achieve the purposes of punishments stated above. The conditions are ${ }^{28}$ :

a. Punishment must be prescribed by Islamic Law (principle of legality). This means that the punishment is based from the Islamic Law sources, namely the Qur'an, As-Sunnah, Ijma, or the law set by the authorized institution (Ulil Amri). The latest must not be in contradiction with the provisions of Islamic law, otherwise it is void.

b. Punishment should be personal (principle of accountability). This implies that it should be imposed only on a person who commits the crime.

c. Punishment must be universal (principle of equality). This means that it is applicable to everyone without discrimination.

\section{Methodology}

This study aims to analyse whether the Islamic Court in Aceh Province implements the international treaties on human rights ratified by Indonesia. To

\footnotetext{
${ }^{23}$ El-Awa (1982) at 2.

${ }^{24}$ El-Awa (1982) at 116.

${ }^{25}$ El-Awa (1982) at 116.

${ }^{26}$ El-Awa (1982) at 110.

${ }^{27}$ Suparyanto (2015).

${ }^{28}$ Suparyanto (2015).
} 
achieve this particular objective, it adopts a normative legal research ${ }^{29}$. Data used in this study was secondary data which consists of ${ }^{30}$ :

a. Primary legal materials, namely International Convention on the Elimination of All Forms of Discrimination against Women (CEDAW), ratified by Law 7 of 1984; Convention International Against Torture and Treatment or Punishment other Cruel, Inhuman and Degrading Man's Dignity (CAT), ratified by Law 5 of 1998; International Convention on Elimination of All Forms of Racial Discrimination (CERD), ratified with Law 29 of 1999; International Convention on the Rights of the Child (CRC), ratified through Presidential Decree No. 36 of 1990; International Covenant on Economic, Social and Cultural Rights (ICESCR), ratified by Law 11 of 2005; The International Covenant on Civil and Political Rights (ICCPR), ratified by law 12 of 2005Law No. 11 of 2006 concerning the Government of Aceh, The Jināyat Qānūn of Aceh Province (Qānūn No.6 of 2014), Presidential Decree No.11 of 2003 concerning Islamic Court (Mahkamah Syar'iyah) and Aceh Islamic Court Decisions.

b. Secondary legal materials, namely books, research reports and journal articles.

All data collected were analysed based on their content (content analysis) using the qualitative approach. ${ }^{31}$ There are five main steps employed in the process of analysing the materials listed above. They are:

Step 1: categorizing the secondary data which consists of laws, cases, experts' arguments obtained from books, research reports and journals

Step 2: identifying the issues and categorizing the arguments (pros and cons arguments) based on the identified issues.

Step 3: summarizing the relevant issues and arguments obtained from Step 2. The summaries that are originally written in Indonesia to be translated into English.

Step 4: critically reviewing and analysing the summaries.

Step 5: establishing analytical arguments in order to produce compelling conclusions pursuant to the summarized materials obtained from Step 4.

\section{Findings}

The Jināyat Qānūn of Aceh Province (Qānūn No.6 of 2014) consists of ten chapters, namely General Provisions (Chapter I), Principles and Scope (Chapter II), Reason and Rejection Reason (Chapter III), Jarìmah and 'Uqūbat (Chapter IV), Bonding Jarimah (Chapter V), Jarimah and (Chapter VII), Other Requirements

\footnotetext{
${ }^{29}$ Soejono \& Abdurahman (2003) at 56.

${ }^{30}$ Marzuki (2005).

${ }^{31}$ Qualitative research is a type of scientific research that aims to seek answers to the questions 'what', 'how' or 'why' of a phenomenon. See Coutin (2015).
} 
(Chapter VIII), Transitional Provisions (Chapter IX) and Closing Provisions (Chapter X). Table 3 shows the category of offenses and their punishments under the Jināyat Qānūn of Aceh Province.

Table 3. Offenses and Punishments under the Jināyat Qānūn

\begin{tabular}{|c|c|c|}
\hline $\begin{array}{l}\text { Criminal } \\
\text { Offenses } \\
\text { (Jarīmah) }\end{array}$ & Description & Provisions and Punishment \\
\hline Khamar & $\begin{array}{l}\text { An intoxicating drink and/or } \\
\text { containing alcohols of } 2 \% \text { (two } \\
\text { percent) or more. }\end{array}$ & $\begin{array}{l}\text { Article 15(1): Anyone who } \\
\text { deliberately drinks Khamar is } \\
\text { threatened with 'Uqubat Hudud } \\
\text { by whipping } 40 \text { (forty) times. } \\
\text { Article 15(2): Everyone who } \\
\text { repeats such acts referred to in } \\
\text { paragraph (1) shall be threatened } \\
\text { with 'Uqubat Hudud by } \\
\text { whipping } 40 \text { (forty) times plus } \\
\text { Uqubat Ta'zir by whipping at } \\
\text { most } 40 \text { (forty) times or a fine at } \\
\text { most } 400 \text { (four hundred) grams } \\
\text { of pure gold or imprisonment for } \\
\text { a maximum of } 40 \text { (forty) months. } \\
\text { Article } 16 \text { (1): Any person who } \\
\text { knowingly produces, store/store, } \\
\text { sell, or enter khamar, each is } \\
\text { threatened with 'Uqubat Ta'zir by } \\
\text { whipping at most } 60 \text { (sixty) times } \\
\text { or fine at most } 600 \text { (six hundred) } \\
\text { grams of pure gold or } \\
\text { imprisonment for a maximum of } \\
60 \text { (sixty) months. } \\
\text { Article } 16(2) \text { : Every person who } \\
\text { intentionally buys, carrying/ } \\
\text { transporting, or awarding } \\
\text { Khamar, each is threatened with } \\
\text { 'Uqubat Ta'zir by the most whips } \\
\text { of } 20 \text { (twenty) times or a fine of } \\
\text { at most } 200 \text { (two hundred) grams } \\
\text { of pure gold or a maximum of } 20 \\
\text { (twenty) months imprisonment. } \\
\text { Article } 17 \text { : Any person who } \\
\text { deliberately commits an act as } \\
\text { referred to in Articles } 15 \text { and } 16 \\
\text { with involving children subject to } \\
\text { 'Uqubat Ta'zir by whipping at } \\
\text { most } 80 \text { (eighty) times or a } \\
\text { maximum fine of } 800 \text { (eight } \\
\text { hundred) grams of pure gold or } \\
\text { the longest imprisonment of } 80 \\
\text { (eighty) months. }\end{array}$ \\
\hline
\end{tabular}




\begin{tabular}{|c|c|c|}
\hline Maysīr & $\begin{array}{l}\text { An act that contains the } \\
\text { element of the bet and / or an } \\
\text { element of chance made } \\
\text { between } 2 \text { (two) parties or } \\
\text { more, accompanied by an } \\
\text { agreement that the parties who } \\
\text { wins will get paid / certain } \\
\text { profit from the losers either } \\
\text { directly or indirectly. }\end{array}$ & $\begin{array}{l}\text { Article 18: Everyone who } \\
\text { deliberately performs Jarimah } \\
\text { Maysir with a bet and/or a } \\
\text { maximum of } 2 \text { points (two) } \\
\text { grams of pure gold, is threatened } \\
\text { with 'Uqubat Ta'zir by whipping } \\
\text { at most } 12 \text { (twelve) times or a } \\
\text { maximum fine of } 120 \text { (one } \\
\text { hundred and twenty) grams of } \\
\text { pure gold or the longest } \\
\text { imprisonment of } 12 \text { (twelve) } \\
\text { months. } \\
\text { Article 19: Everyone who } \\
\text { deliberately performs Jarimah } \\
\text { Maysir with a bet value and / or } \\
\text { gain of more than } 2 \text { (two) gram } \\
\text { of pure gold, is threatened under } \\
\text { 'Uqubat Ta'zir with the most } \\
\text { whip many } 30 \text { (thirty) times or a } \\
\text { fine of not more than } 300 \text { (three } \\
\text { hundred) grams of pure gold or } \\
\text { imprisonment not exceeding } 30 \\
\text { (thirty) months. } \\
\text { Article } 20 \text { : Any person who } \\
\text { deliberately organizes, provide } \\
\text { facilities, or finance Jarimah } \\
\text { Maysir as referred to in Articles } \\
18 \text { and } 19 \text { shall be threatened } \\
\text { with 'Uqubat Ta'zir by whipping } \\
\text { at a maximum of } 45 \text { (forty } \\
\text { five) times and/or a fine of not } \\
\text { more than } 450 \text { (four hundred and } \\
\text { five) pure gold gram and/or a } \\
\text { maximum of } 45 \text { months } \\
\text { imprisonment. } \\
\text { Article } 21: \text { Everyone who } \\
\text { deliberately performs Jarimah } \\
\text { Maysir as referred to in Articles } \\
18 \text { and } 19 \text {, which involving } \\
\text { children is threatened with } \\
\text { 'Uqubat Ta'zir involving children } \\
\text { is threatened by whipping at a } \\
\text { maximum of } 45 \text { (forty five) times } \\
\text { or a fine of maximum } 450 \text { (four } \\
\text { hundred fifty) grams of pure gold } \\
\text { or imprisonment of a maximum } \\
\text { of } 45 \text { (forty five) months. } \\
\text { Article } 22: \text { Anyone who attempts } \\
\text { to do the Jarimah Maysir as } \\
\text { referred to in Articles } 18 \text { and } 19 \\
\text { shall be liable 'Uqubat Ta'zir is at }\end{array}$ \\
\hline
\end{tabular}




\begin{tabular}{|c|c|c|}
\hline & & $\begin{array}{l}\text { most } 1 / 2 \text { (half) of' Uqubat which } \\
\text { is threatened. }\end{array}$ \\
\hline Khalwat & $\begin{array}{l}\text { An act of being in a closed } \\
\text { place or hidden between } 2 \\
\text { (two) people of different types } \\
\text { sex which is not } M^{32 h a m^{32}} \text { and } \\
\text { without marital ties with the } \\
\text { willingness of both parties that } \\
\text { leads to fornication. }\end{array}$ & $\begin{array}{l}\text { Article 23: (1) Everyone who } \\
\text { deliberately does the Jarimah } \\
\text { khalwat, is threatened with } \\
\text { 'Uqubat Ta'zir by the most } \\
\text { whipping of } 10 \text { (ten) times or the } \\
\text { most fine of } 100 \text { (one hundred) } \\
\text { grams of pure gold or the longest } \\
\text { imprisonment of } 10 \text { (ten) months. } \\
\text { (2) Every person who } \\
\text { deliberately organizes, provide } \\
\text { facilities or promote Jarimah } \\
\text { khalwat, is threatened with } \\
\text { 'Uqubat Ta'zir by the most } \\
\text { whipping of } 15 \text { (fifteen) times } \\
\text { and/or a maximum fine } 150 \text { (one } \\
\text { hundred and fifty) grams of pure } \\
\text { gold and/or imprisonment at a } \\
\text { maximum of } 15 \text { (fifteen) months. }\end{array}$ \\
\hline Ikhtilath & $\begin{array}{l}\text { The act of touching, hugging } \\
\text { and kissing between a man and } \\
\text { a woman who is not a husband } \\
\text { and wife with a willingness of } \\
\text { both sides, either in a closed or } \\
\text { open place. }\end{array}$ & $\begin{array}{l}\text { Article 25: } \\
\text { (1) Everyone who deliberately } \\
\text { does the Jarimah Ikhtilath, is } \\
\text { threatened with 'Uqubat by } \\
\text { whipping } 30 \text { (thirty) times at the } \\
\text { most or a fine of not more than } \\
300 \text { (three hundred) gram of pure } \\
\text { gold or imprisonment not later } \\
\text { than } 30 \text { (thirty) months. } \\
\text { (2) Every person who } \\
\text { deliberately organizes, provide } \\
\text { facilities or promote Jarimah } \\
\text { Ikhtilath, is threatened with } \\
\text { 'Uqubat Ta'zir by whipping } 45 \\
\text { (forty five) times at the most } \\
\text { and/or the most fine of } 450 \text { (four } \\
\text { hundred fifty) grams of pure gold } \\
\text { And/or imprisonment of a } \\
\text { maximum of } 45 \text { (forty five) } \\
\text { months. } \\
\text { Article } 26 \text { : Any person who } \\
\text { deliberately performs Jarimah } \\
\text { Ikhtilath as referred to in Article } \\
25 \text { with a child whose age is over } \\
10 \text { (ten) years, is threatened with }\end{array}$ \\
\hline
\end{tabular}

\footnotetext{
${ }^{32}$ Mahram is very close relatives or family members that you are not allowed to marry. They are your children, grandchildren, mother, father, grandfather, grandmother, maternal grandfather, maternal grandmother, brothers, sisters whether real or children of the same father or of the same mother, uncle, niece, maternal uncle and niece, maternal aunt and nephew, paternal aunt and nephew, foster brother and sister. See Madani (2001) at 487-488.
} 


\begin{tabular}{|c|c|c|}
\hline & & $\begin{array}{l}\text { 'UqubatTa'zir by whipping at a } \\
\text { maximum of } 45 \text { (forty five) times } \\
\text { or a fine of not more than } 450 \\
\text { (four hundred and fifty) grams of } \\
\text { gold pure or imprisonment of a } \\
\text { maximum of } 45 \text { (forty five) } \\
\text { months. } \\
\text { Article 27: Any person who } \\
\text { deliberately performs Jarimah } \\
\text { Ikhtilath with people who have } \\
\text { Mahram associated with him, in } \\
\text { addition to be threatened with } \\
\text { 'Uqubat as referred to in Article } \\
25 \text { paragraph (1), it may be } \\
\text { supplemented by 'Uqubat Ta'zir' } \\
\text { at the maximum fine of } 30 \\
\text { (thirty) grams of pure gold or } \\
\text { 'Uqubat Ta'zir of imprisonment } \\
\text { for a maximum of } 3 \text { (three) } \\
\text { months. }\end{array}$ \\
\hline Zina & $\begin{array}{l}\text { Intercourse between a man or } \\
\text { more with a woman or more } \\
\text { without marriage bonds } \\
\text { with the willingness of both } \\
\text { parties. }\end{array}$ & $\begin{array}{l}\text { Article } 33 \\
\text { (1) Any Person who deliberately } \\
\text { committed the Zina Jarimah, is } \\
\text { threatened with 'Uqubat Hudud } \\
\text { by whipping } 100 \text { (one hundred) } \\
\text { times. } \\
\text { (2) Everyone who repeats such } \\
\text { acts referred to in paragraph (1) } \\
\text { shall be threatened with 'Uqubat } \\
\text { Hudud by whipping } 100 \text { (one } \\
\text { hundred) times and can be } \\
\text { supplemented with 'Uqubat } \\
\text { Ta'zir of a maximum fine of } 120 \\
\text { (one hundred and twenty) gram } \\
\text { of pure gold or 'Uqubat Ta'zir of } \\
\text { imprisonment not more than } 12 \\
\text { (Twelve) months. } \\
\text { (3) Any person and/or business } \\
\text { entity intentionally provides } \\
\text { facilities or promote Jarimah } \\
\text { Zina, is threatened with 'Uqubat } \\
\text { Ta'zir by whipping at maximum } \\
\text { of } 100 \text { ane hundred) times and/or a fine } \\
\text { (one } \\
\text { which is not more than } 1000 \text { (one } \\
\text { thousand) grams of pure gold } \\
\text { and/or a maximum of } 100 \\
\text { (One hundred) } \\
\text { imprisonment. } \\
\text { Article } 34 \text { : Any adult who } \\
\text { commits Zina with a child, is }\end{array}$ \\
\hline
\end{tabular}




\begin{tabular}{|c|c|c|}
\hline & & $\begin{array}{l}\text { threatened with 'Uqubat Hudud } \\
\text { as referred to in Article } 33 \\
\text { paragraph (1), it may be } \\
\text { supplemented by 'Uqubat Ta'zir } \\
\text { by whipping at a maximum of } \\
100 \text { (one hundred) times or a } \\
\text { maximum fine of } 1,000 \text { (one } \\
\text { thousand) grams of pure gold or } \\
\text { imprisonment of } 100 \text { (one } \\
\text { hundred) months. } \\
\text { Article 35: Any person who } \\
\text { deliberately commits the Zina } \\
\text { Jarimah with the people who } \\
\text { have Mahram associated with } \\
\text { him, is threatened with 'Uqubat } \\
\text { as referred to in Article } 33 \\
\text { paragraph (1), it may be } \\
\text { supplemented by 'Uqubat Ta'zir' } \\
\text { at a maximum fine of } 100 \text { (one } \\
\text { hundred) grams of pure gold or } \\
\text { 'Uqubat Ta'zir of maximum } 10 \\
\text { (ten) months imprisonment. }\end{array}$ \\
\hline $\begin{array}{c}\text { Sexual } \\
\text { Harassment }\end{array}$ & $\begin{array}{l}\text { An act of immorality or deed } \\
\text { obscene that someone is } \\
\text { deliberately committed in } \\
\text { public or against others as } \\
\text { victims of both men and } \\
\text { women without victim's } \\
\text { willingness. }\end{array}$ & $\begin{array}{l}\text { Article 46: Everyone who } \\
\text { deliberately does Jarimah sexual } \\
\text { harassment, is threatened with } \\
\text { 'Uqubat Ta'zir by whipping } \\
\text { At a maximum } 45 \text { (forty five) } \\
\text { times or a maximum fine of } 450 \\
\text { (four hundred fifty) grams of } \\
\text { pure gold or a maximum of } 45 \\
\text { (forty five) months imprisonment. } \\
\text { Article 47: Everyone who } \\
\text { deliberately does Jarimah Sexual } \\
\text { Harassment as referred to in } \\
\text { Article } 46 \text { against a child, is } \\
\text { threatened with 'Uqubat Ta'zir by } \\
\text { a maximum whipping of } 90 \\
\text { (ninety) times or a maximum fine } \\
\text { of } 900 \text { (nine hundred) grams of } \\
\text { pure gold or a maximum of } 90 \\
\text { (ninety) months imprisonment. }\end{array}$ \\
\hline Rape & $\begin{array}{l}\text { Sexual intercourse with victim's } \\
\text { faraj or rectum with an } \\
\text { offender's faraj or rectum or } \\
\text { other objects used by the } \\
\text { offender against victim's mouth, } \\
\text { vice versa, by force or coercion } \\
\text { or threat to the victim. }\end{array}$ & $\begin{array}{l}\text { Article 48: Everyone who } \\
\text { deliberately does Jarimah Rape } \\
\text { is threatened with 'Uqubat Ta'zir } \\
\text { by whipping minimum } 125 \text { (one } \\
\text { hundred and twenty-five) times, } \\
\text { maximum } 175 \text { (one hundred and } \\
\text { seventy five) times or a fine of } \\
\text { minimum 1,250 (one thousand } \\
\text { two hundred fifty) grams of pure }\end{array}$ \\
\hline
\end{tabular}




\begin{tabular}{|c|c|c|}
\hline & & $\begin{array}{l}\text { gold, maximum } 1,750 \text { (one } \\
\text { thousand seven hundred and } \\
\text { fifty) pure gold grams or } \\
\text { minimum } 125 \text { (one hundred and } \\
\text { twenty five) months } \\
\text { imprisonment, maximum 175 } \\
\text { (one hundred and seventy five) } \\
\text { months imprisonment. } \\
\text { Article 49: Everyone who } \\
\text { deliberately does Jarimah Rape } \\
\text { of people who have a Mahram } \\
\text { relationship with him, is } \\
\text { threatened with 'Uqubat Ta'zir by } \\
\text { whipping minimum } 150 \text { (one } \\
\text { hundred and fifty) times, } \\
\text { maximum 200 (two hundred) } \\
\text { times or a fine of minimum } 1,500 \\
\text { (one thousand five hundred) } \\
\text { gram of pure gold, maximum } \\
2,000 \text { (two thousand) grams of } \\
\text { gold pure or imprisonment of } \\
\text { minimum } 150 \text { (one hundred and } \\
\text { fifty) month, maximum } 200 \text { (two } \\
\text { hundred) months. } \\
\text { Article } 50 \text { : Everyone who } \\
\text { deliberately does Jarimah Rape } \\
\text { as referred to in Article } 48 \\
\text { against child is threatened with } \\
\text { 'Uqubat Ta'zir by whipping } \\
\text { minimum } 150 \text { (one hundred and } \\
\text { fifty) times, maximum } 200 \text { (two } \\
\text { hundred) times or a fine of } \\
\text { minimum } 1,500 \text { (one thousand } \\
\text { five hundred) grams of pure } \\
\text { gold, maximum } 2,000 \text { (two } \\
\text { thousand) grams of pure gold or } \\
\text { imprisonment of minimum } 150 \\
\text { (one hundred and fifty) months, } \\
\text { maximum } 200 \text { (two hundred) } \\
\text { months. } \\
\text { Article } 51 \text { (1): } \\
\text { In the case of a victim's request, } \\
\text { any person who is subject to } \\
\text { 'Uqubat as referred to in Article } \\
48 \text { and Article } 49 \text { may be subject } \\
\text { to a maximum 'Restricted } \\
\text { Uqubat of } 750 \text { (seven hundred } \\
\text { and fifty) grams of pure gold. }\end{array}$ \\
\hline Qadzaf & $\begin{array}{l}\text { Accusing someone of Zina } \\
\text { without presenting at least } 4 \\
\text { (four) witnesses. }\end{array}$ & $\begin{array}{l}\text { Article 57: } \\
\text { (1) Any person who deliberately } \\
\text { performs Qadzaf is threatened }\end{array}$ \\
\hline
\end{tabular}




\begin{tabular}{|c|c|c|}
\hline & & $\begin{array}{l}\text { with 'Uqubat Hudud by } \\
\text { whipping } 80 \text { (eighty) times. } \\
\text { (2) Everyone who repeats the } \\
\text { deeds as it is referred to in } \\
\text { paragraph (1) shall be threatened } \\
\text { with 'Uqubat Hudud by } \\
\text { whipping } 80 \text { (eighty) times and } \\
\text { can be supplemented by 'Uqubat } \\
\text { Ta'zir fines maximum } 400 \text { (four } \\
\text { hundred) grams pure gold or } \\
\text { 'Uqubat Ta'zir for a maximum of } \\
40 \text { (forty) months imprisonment. } \\
\text { Article } 58 \text {; } \\
\text { (1) In the case of any defendant's } \\
\text { request, any person who is } \\
\text { subject to 'Uqubat as referred to } \\
\text { in Article } 55 \text { may be subjected to } \\
\text { 'Uqubat Restitution at maximum } \\
400 \text { (four hundred) grams of pure } \\
\text { gold. }\end{array}$ \\
\hline Liwath & $\begin{array}{l}\text { The deed of a man by the way } \\
\text { putting his penis into another } \\
\text { male's rectum with the } \\
\text { willingness of both parties. }\end{array}$ & $\begin{array}{l}\text { Article 63: } \\
\text { (1) Everyone who deliberately } \\
\text { does the Jarimah Liwath is } \\
\text { threatened with 'Uqubat Ta'zir } \\
\text { by whipping at maximum } 100 \\
\text { (one hundred) times or a fine of } \\
\text { at maximum } 1,000 \text { (one } \\
\text { thousand) grams of pure gold or } \\
\text { a maximum of } 100 \text { (one } \\
\text { hundred) months imprisonment. } \\
\text { (2) Everyone who repeats such } \\
\text { acts referred to in paragraph (1) } \\
\text { shall be threatened with 'Uqubat } \\
\text { Ta'zir by whipping } 100 \text { (one } \\
\text { hundred) times and can be added } \\
\text { with a fine at maximum } 120 \text { (one } \\
\text { hundred and twenty) grams of } \\
\text { pure gold and / or imprisonment } \\
\text { of no more than } 12 \text { (twelve) } \\
\text { months. } \\
\text { (3) Any Person who does Liwath } \\
\text { with a child, in addition to be } \\
\text { threatened with 'Uqubat Ta'zir as } \\
\text { referred to in paragraph (1) may } \\
\text { be added with a whip of at } \\
\text { maximum } 100 \text { (one hundred) } \\
\text { times or a fine of not more than } \\
1,000 \text { (one thousand) grams pure } \\
\text { gold or a maximum of } 100 \text { (one } \\
\text { hundred) months imprisonment. }\end{array}$ \\
\hline
\end{tabular}




\begin{tabular}{|c|c|c|}
\hline Musahaqah & $\begin{array}{l}\text { The deed of two or more } \\
\text { women by mutually rubbing } \\
\text { limbs or faraj to obtain sexual } \\
\text { stimulation (pleasure) with the } \\
\text { willingness of both parties. }\end{array}$ & $\begin{array}{l}\text { Article 64: } \\
\text { (1) Everyone who deliberately } \\
\text { does the Jarimah Musahaqah is } \\
\text { threatened with 'Uqubat Ta'zir by } \\
\text { whipping at maximum of } 100 \\
\text { (one hundred) times or a fine of } \\
\text { at maximum of } 1,000 \text { (one } \\
\text { thousand) grams of pure gold or } \\
\text { a maximum of } 100 \text { (one hundred) } \\
\text { months imprisonment. } \\
\text { (2) Everyone who repeats such } \\
\text { acts as referred to in paragraph } \\
\text { (1) shall be threatened with } \\
\text { 'Uqubat Ta'zir by whipping } 100 \\
\text { (one hundred) times and can be } \\
\text { added with a fine at maximum of } \\
120 \text { (one hundred and twenty) } \\
\text { grams of pure gold and / or } \\
\text { imprisonment of no more than } 12 \\
\text { (twelve) months. } \\
\text { (3) Anyone who does the } \\
\text { Jarimah Musahaqah with } \\
\text { children, in addition to being } \\
\text { threatened with 'Uqubat Ta'zir as } \\
\text { referred to in paragraph (1) may } \\
\text { be supplemented by whipping at } \\
\text { maximum of } 100 \text { (one hundred) } \\
\text { times or a maximum fine of } \\
1,000 \text { (one thousand) grams of } \\
\text { pure gold or a maximum of } 100 \\
\text { (one hundred) } \\
\text { imprisonment. }\end{array}$ \\
\hline
\end{tabular}

Source: Qānūn No.6 of 2014 concerning Jināyat Law (Criminal Law)

The punishment by whipping under Qānūn No.6 of 2014 is done by rattan which has a diameter between $0.75 \mathrm{~cm}$ to 1 (one) centimetre, 1 meter long without a double edge/split. It is conducted in public. Offenders must wear white clothes. Women must cover their heads. The executor must cover the face and head to cover the identity.

Data from the Acehnese Child and Woman Protection Agency stated that there were 428 cases in 2013, 515 cases in 2014 and 548 cases in 2015. At least 108 people are executed by caning law. The Institute for Criminal Justice Reform found at least 180 prisoners have been executed by whipping sentences throughout Aceh Province. Data from the Institute for Criminal Justice Reform (ICJR) recorded that the Aceh Shariah Court made at least 221 decisions on jinayat cases from January to September 2016. Five major areas where the jinayat case decided are: 
Vol. 5, No. 1 Shahrullah: Revisiting Implementation of Treaties on Human Rights...

1. Banda Aceh: 40 cases;

2. Kualasimpang: 29 cases;

3. Kutacane: 24 cases;

4. Blangkejeren and Jantho: 21 cases;

5. Langsa: 17 cases. $^{33}$

Based on the annual report of the Supreme Court of Indonesia, 274 cases were decided in 2017 for various categories, namely:

1. Maysìr $: 113$ cases.

2. Ikhtilath: 64 cases.

3. Zina: 24 cases.

4. Sexual Harassment: 24 cases.

5. Khamar: 19 cases.

6. Khalwat: 21 cases.

7. Rape: 7 cases.

8. Liwath: 2 cases. $^{34}$

\section{Discussion}

Article 128 of Law No. 11 of 2006 concerning the Government of Aceh stipulates that the implementation of Shariah law in the life of Acehnese people is within the national legal system in the Unitary State of Republic of Indonesia (NKRI). This provision implies that international treaties ratified by Indonesia have to be reflected in the Aceh Qānūn. Hikmahanto Juwana asserts that international agreements on human rights have the substance of formation norm (law making), consequently a ratifying state has an obligation to transforming them into their national law. Accordingly, the international human rights legal instruments require Indonesia as a ratifying state to transforming the existing principles and norms of the treaties into its applicable and existing legislation. ${ }^{35}$ Article 2 paragraph (2) of the ICCPR and Article 2 paragraph (1) of the ICESCR requires the state to take legislative measures to include provisions in both covenants at the national level. Article 2 of CEDAW obliges also the state to take all appropriate steps to establish a policy of elimination of all form of racial discrimination. It also emphasizes the importance of reform the state laws to ensure the promotion of women's human rights. Similarly, Article 4 paragraph (1) of the CERD and Article 4 of the CRC requires that a state to take appropriate legislative, administrative and other measures to implement the norms of the Convention. Accordingly, all Indonesian legislation including the Aceh Qānūn the must reflect the international norms and principles of the ratified Conventions.

However, the Aceh Jinayat Qānūn which imposes the carrying out of the punishment on offenders by using rattan canning raises controversies among most

\footnotetext{
${ }^{33}$ Institute for Criminal Justice Reform (ICJR) (2016).

${ }^{34}$ Laporan Tahunan Mahkamah Agung 2017 (2017)

${ }^{35}$ Juwana (2010).
} 
Indonesian jurists because the punishment system in Indonesia strictly prohibits the use of caning. Many of international jurists also consider that it violates human rights and international treaties ratified by Indonesia in the field of human rights. Table 4 shows the punishment in Aceh Province which are regarding as the violations of international treaties ratified by Indonesia.

\begin{tabular}{|c|c|c|}
\hline $\begin{array}{l}\text { Criminal } \\
\text { Offenses } \\
\text { (Jarīmah) } \\
\end{array}$ & Case Descriptions & $\begin{array}{l}\text { Punishment } \\
\text { ('Uqūbat) }\end{array}$ \\
\hline \multirow[t]{2}{*}{ Khamar } & $\begin{array}{c}\text { The case of Miftahul Alias MIP } \\
\text { bin Jusran. The case number 10/ } \\
\text { JN.S/2015/MS.KC. He was } \\
\text { convicted legally guilty to drink } \\
\text { alcohol. }\end{array}$ & 40 lashes in public \\
\hline & $\begin{array}{l}\text { The case Rita Sinaga (Non } \\
\text { Muslim) was convicted legally } \\
\text { guilting of selling alcohol. }\end{array}$ & $\begin{array}{c}28 \text { lashes in public at the } \\
\text { Takismon Arts House (GOS) of } \\
\text { Takengon, Central Aceh }\end{array}$ \\
\hline \multirow[t]{2}{*}{ Maysīr } & $\begin{array}{l}\text { The case Gunawan Wahyudin } \\
\text { Als.Gogon Bin Zakaria. The case } \\
\text { Number JN.S / } 2016 \text { / MS.KC. } \\
\text { He was convicted legally guilty } \\
\text { to gambling. }\end{array}$ & $\begin{array}{l}7 \text { lashes in public minus the } \\
\text { prison days that was undertaken } \\
\text { by the offender during the } \\
\text { investigation process. }\end{array}$ \\
\hline & $\begin{array}{l}\text { Alem Suhadi and Amel Akim } \\
\text { (Non Muslim).They were found } \\
\text { guilty of cockfighting. }\end{array}$ & $\begin{array}{c}9 \text { lashes (Alem Suhadi) and } 7 \\
\text { lashes (Amel Akim) in public. } \\
\text { Their sentences were mitigated } \\
\text { because they had spent over a } \\
\text { month in detention }\end{array}$ \\
\hline Khalwat & $\begin{array}{l}\text { The case of Ramli Tampubolon } \\
\text { Als. Ramli (Christian) and } \\
\text { Luciana Als. Uci Binti Mahyudin } \\
\text { (Muslim). The case Number } 03 \text { / } \\
\text { JN.S/2016/MS.KC. They were } \\
\text { convicted legally guilty to } \\
\text { conduct Khalwat. }\end{array}$ & $\begin{array}{l}8 \text { lashes in public less the number } \\
\text { of prison days that were } \\
\text { undertaken by the offender } \\
\text { during the investigation process. }\end{array}$ \\
\hline Ikhtilāț & $\begin{array}{l}\text { The case of Sa who was } \\
\text { convicted legally guilty to } \\
\text { conduct Ikhtilāț. }\end{array}$ & $\begin{array}{c}20 \text { lashes in public at Al Furqan } \\
\text { Mosque, Gampong Beurawe, } \\
\text { Kuta Alam Sub-district, Banda } \\
\text { Aceh. }\end{array}$ \\
\hline Zina & $\begin{array}{c}\text { Two people of Kampung Burlah } \\
\text { residents. They were convicted } \\
\text { legally guilty of Zina. }\end{array}$ & $\begin{array}{l}100 \text { lashes respectively in public } \\
\text { at Tugu Blangkejeren, Gayo Lues } \\
\text { district. }\end{array}$ \\
\hline Rape & $\begin{array}{l}\text { The case of Ali Imran Bin Abdul } \\
\text { Samad. The case Number } 0004 \text { / } \\
\text { JN / } 2016 \text { / MSY-TTN. He was } \\
\text { convicted legally guilty of rape. }\end{array}$ & $\begin{array}{l}125 \text { lashes in public at Istiqamah } \\
\text { Tapaktuan Grand Mosque. }\end{array}$ \\
\hline Liwāṭ & $\begin{array}{l}\text { MT and MH were found guilty of } \\
\text { conducting Liwath or similar } \\
\text { relationships. }\end{array}$ & 82 lashes in public. \\
\hline
\end{tabular}

Source: Compiled by the author. 
The implementation of caning penalty in Aceh Province is frequently criticized by international community on the grounds that it can be categorized as torture, inhuman and degrading punishment; consequently it violates the ICCPR which has been ratified by Indonesia. ${ }^{36}$ Article 7 of the ICCPR states that 'No one shall be subjected to torture or to cruel, inhuman or degrading treatment or punishment'. In addition, the execution does not only cause physical pain, but also mental torture because it is conducted in public. ${ }^{37}$ The public display also results in a culture of violence in Aceh society. ${ }^{38}$ In 2013, the UN Human Rights Committee whose functions to monitor the state compliance with their obligations under the ICCPR, calls on Indonesia to repeal the Aceh Qānūn because it does not comply with the ICCPR. From international law perspectives, Indonesia fails to undertake its obligations under the ICCPR. However, Head of Public Relation Bureau of Aceh Government, Frans Delian claimed that the Jinayat Qānūn is effective since none of offenders repeat their offenses. In addition, Aceh society has supported the implementation of the Jinayat Qānūn as it can be proved that Non Muslims preferred to choose to be punished under the Islamic Law even though they have option to be punished under the Indonesian Criminal Code. ${ }^{39}$ Similarly, Alem (Non Muslim) who was caned due to gambling offense asserted that "we live in Aceh, so we have to obey the regulations in our region'. ${ }^{40}$ This reveals that the offender accepted the consequences of the offense without objecting to it.

It is also advanced that the caning punishment is also a violation of CAT. Hence, in 2008 the UN Anti-Torture Committee requested Indonesia to evaluate and eliminate its national and local law products which impose harsh punishment that can be categorized as acts of torture. ${ }^{41}$ This is a manifestation of Article 2(1) of CAT which states that 'each State Party shall take effective legislative, administrative, judiciary or other measures to prevent acts of torture in any territory under its jurisdiction'. Head of Public Relation Bureau of Aceh Government, Frans Delian asserted that up to now the Central Government has not called on the Aceh Government to review the implementation of Jinayat Qānūn. He objected if its implementation is considered as a violation of human rights since the caning punishment is not as cruel as people imagine. He said that "no one who has been canned is taken to the Intensive Care Unit'. ${ }^{2}$

Ayu Ezra Tiara of the Indonesian Legal Aid Foundation claimed that the execution of caning penalty in public violates the protection of children since they are allowed to watch it. This apparently violates Article 6(2) of the CRC which requires 'states parties shall ensure to the maximum extent possible the survival and development of the child'. The display of caning execution may impact on the psychology development of children. ${ }^{43}$ The Coordinator of Women Solidarity

\footnotetext{
${ }^{36}$ Madani (2001) at 487-488.

${ }^{37}$ Abidin (2011) at 39.

${ }^{38}$ Madani (2001) at 487-488.

${ }^{39}$ Artharini (2016).

${ }^{40}$ The Straits Times (2017).

${ }^{41}$ Madani (2001) at 487-488.

${ }^{42}$ Wardah (2014).

${ }^{43}$ Wardah (2014). The Aceh Governor issued a Governor Regulation No. 5 of 2018 concerning the Implementation of Jinayat Procedural Law which regulates that the place of the caning punishment
} 
Program, Nisa Yura pointed out that the Jinayat Qānūn is discriminative against women. She said that 'if a woman reported that she was raped but she was unable to prove, the accused man could sue back on the ground of defamation'. It is obvious that a violation of CEDAW occurs since Article 2 of CEDAW requires a state party to 'establish legal protection of the rights of women on an equal basis with men and to ensure through competent national tribunals and other public institutions the effective protection of women against any act of discrimination'. In addition, Nisa Yura argues that a caning punishment to a woman causes not only physical but also psychological impacts because it is conducted in public without a face cover. It may lead to exclusion or discrimination to the female offender after the punishment because women are always considered as a moral guard. ${ }^{44}$ Apart from the controversies regarding the implementation of the Jinayat Qānūn and the compliance of the Aceh Islamic Court to international treaties ratified by Indonesia, people of Aceh remain to support the Islamic Law to govern their life as it is reflected from the Aceh proverbs 'hukom nanggro keupakaian, hukom Tuhan keu kulahkama' which means 'state law is for dress, God's law is for crown'.

\section{Conclusion}

Indonesia as a member of international community has ratified six international treaties in the fields of human rights. Criticisms regarding the implementation of international treaties in the Islamic Court of Aceh has arisen controversies due to the implementation of caning punishment which are considered inhuman and cruel. International community and the UN Human Rights Committee request Indonesia to repeal the Aceh Qānūn to comply with the ratified international treaties. Up to now, there is no action taken by the Central government of Indonesia since it considers that Aceh society obeys the implementation of Jinayat Qānūn. It can be concluded that in addition to the Government, people of Aceh support the Qānün which is based on Islamic Law to govern their life as it is reflected from the Aceh proverbs 'hukom nanggro keupakaian, hukom Tuhan keu kulahkama' which means 'state law is for dress, God's law is for crown'.

should be carried out in the correctional institution. The purpose of the Regulation is that the carrying out of the punishment will not be watched by children nor be recorded by TV reporters by using cellphones or cameras. Today, the controversies against the Regulation still occur in Aceh society. See Serambinews (2018).

${ }^{44}$ Wardah (2014). 


\section{References}

Abidin, Z. (2011). 'Analisis Qanun Syariat Islam Aceh dari Perspektif Kovenan Internasional Hak-hak Sipil Politik (KIHSP)', in Analisis Qanun-Qanun Aceh Berbasis Hak Asasi Manusia. Jakarta: Demos, 1-54

Abubakar, A. (2007). Kajian Undang-Undang Pemerintahan Aceh dan Essay Tentang Perempuan, Perkawinan dan Perwalian Anak. Dinas Syariat Islam, Provinsi Nanggroe Aceh Darussalam

Artharini, I. (2016). 'Penerapan perda syariat Islam di Aceh diminta dikaji ulang, at http:// www.bbc.com/indonesia/indonesia/2016/10/161023_indonesia_setahun_qanun_jinayah

Cammack, M.E. \& R.M. Feener (2012). 'The Islamic Legal System in Indonesia' in Pacific RIM Law \& Policy Journal 21(1):13-42.

Coutin, S.B. (2015). Qualitative research in law and social science. Department of Criminology, Law, and Society (Boston). At http://www.wjh.harvard.edu/nsfqual/Cou tin\%20Paper.pdf

El-Awa, M.S. (1982). Punishment in Islamic Law. Indiana: American Trust Publications

Ibrahim Abu-Harb, I.A. (1997). A Brief Illustrated Guide To Understanding Islam. Darussalam.

Institute for Criminal Justice Reform (ICJR) (2016). Setahun Qanun Jinayat Penggunaan Hukuman Cambuk Yang Semakin Eksesif Di Aceh, at http://icjr.or.id/setahun-qanunjinayat-penggunaan-hukuman-cambuk-yang-semakin-eksesif-di-aceh

Juwana, H. (2010). Hukum Internasional dalam Perspektif Indonesia sebagai Negara Berkembang.Yarsif Warampone

Kasim, I. (2011). 'Qanun di Nanggroe Aceh dan Kompatibalitasnya dengan Hak Asasi Manusia', in Analisis Qanun-Qanun Aceh Berbasis Hak Asasi Manusia, ix-xxi

Laporan Tahunan Mahkamah Agung 2017 (The Supreme Court Report 2017) cited by Detiknews, 5 March 2018, '274 Orang Kena Perda Jinayat Aceh Kurun 2017, Homoseks 2 Kasus', at https://news.detik.com/berita/d-3898473/274-orang-kena-per da-jinayat-aceh-kurun-2017-homoseks-2-kasus

Madani, M.M.A.E. (2001). A Gift for Muslim Women. New Delhi: Idara.

Marzuki, P.M. (2005). Penelitian Hukum. Jakarta: Penerbit Kencana

Marzuki, P. M. (2012). An Introduction to Indonesian Law. 2nd ed. Indonesia: Setara Press.

Mawardi, A. I. (2003). 'The Political Backdrop of the Enactment of the Compilation of Islamic Laws in Indonesia' in Arskal Salim \& Azyumardi Azra (eds.) Sharia and Politics In Modern Indonesia. Pasir Panjang, Singapore: ISEAS. 125-148.

Serambinews (2018). 15 April 2018, 'Pergub "Cambuk di LP" Ditanggapi Prokontra, at http://aceh.tribunnews.com/2018/04/15/pergub-cambuk-di-lp-ditanggapi-prokontra

Soejono, H.A. (2003). Metode Penelitian Hukum. Rineke Cipta.

Suparyanto, A. (2015). "Implementasi Hukuman Cambuk Dalam Perspektif Pendidikan Islam", in Tadarus: Jurnal Pendidikan Islam 4(2).

The Straits Times (2017). Non-Muslims caned for first time under Aceh's syariah law. At http://www.straitstimes.com/asia/se-asia/non-muslims-caned-for-first-time-underacehs-syariah-law

Wardah, F. (2014). Qanun Jinayat di Aceh Melanggar Hak Asasi Manusia. At https:// www.voaindonesia.com/a/qanun-jinayat-di-aceh-melanggar-hak-asasi-manusia/35700 54.html

Zahrah, A. M. (n.d.) al- 'Uqūbah; al-Jarīmah wa 'l- 'Uqūbah fì al-Islām. Cairo: Dar al-Fikr al-'Arabi). 